http://jmscr.igmpublication.org/home/ ISSN (e)-2347-176x ISSN (p) 2455-0450 crossref DOI: https://dx.doi.org/10.18535/jmscr/v9i8.23

\title{
To Estimate Serum Testosterone in Patients of Diabetes Type 2 Having Metabolic Syndrome
}

\author{
Authors \\ Dr Sushmita $^{1^{*}}$, Dr Gaurav Chaudhary ${ }^{1}$, Dr Surya Prakash ${ }^{1}$ \\ ${ }^{1}$ Senior resident KPS Institute of General Medicine Kanpur \\ *Corresponding Author \\ Dr Sushmita
}

\begin{abstract}
Objective: To estimate serum testosterone level in male patients of diabetes type 2 having metabolic syndrome.

Background: Major public health issue faced by the world in present century is diabetic mellitus and the prevalence is also increasing explosively, low testosterone levels in men is one of the diabetic related complication.

Methods: This was a prospective population based study of sixty seven diabetic male patients aged $36-70$ years (median 56.36 $=10.26$ ) reaching emergency and OPD having metabolic syndrome and were evaluated for serum testosterone levels.

Results: sixty Seven male patients with type 2 diabetes mellitus were enrolled during the study period. The mean age of study population was 56.36 \pm 10.26 years (range 36-70), while that of control group patients was found to be $39.80 \pm 7.92$ years. The total number of patients who had BMI of more than $25 \mathrm{~kg} / \mathrm{m}^{2}$, were 19 and all these have low levels of testosterone $(<241 \mathrm{ng} / \mathrm{dl}$ ) which is significant ( $p$ value $<0.001)$.Total number of patient having triglyceride level $>150 \mathrm{mg} / \mathrm{dl}$ were 17 and all these have low levels of testosterone which is significant ( $p$ value $<0.001$ ) The mean HbAlc in study group was $8.83 \pm 1.95 \%$, which was significantly higher as compared to control group with HbAlc $4.82 \pm 0.40$.

Conclusions: The present study highlighted that significant difference in serum total testosterone level has been observed in patients of metabolic syndrome $(X 2=55.7, P=0.0001)$.
\end{abstract}

\section{Introduction}

Testosterone is a hormone having role in sexual function. It has been reported low in patients of type 2 diabetic mellitus (DM), and there is growing interest on linkage of some correlation between serum testosterone level in DM with cooccurrence of metabolic syndrome more on that, testosterone is also associated with risk for cardiovascular disease thus leading to significantly higher prevalence of coronary heart disease (CHD) in men as compared to women. Elderly men with DM often have low circulating serum testosterone level and clinical studies are being conducted to test whether normalization of circulating testosterone levels might leads to improvement of the metabolic control in men with diabetes type 2 and the wide array of its complications. 


\section{Material and Method}

\section{Source of Data}

Patients reaching LLRH hospital with diagnosed case of type 2 diabetes mellitus for five years without any co morbidities and willing to take part in study were included in the study. This study was approved by the local ethical committee of GSVM medical college

\section{Method of Collection Data}

Study Design: Cross sectional study

Place of Study: This analysis was conducted at K.P.S postgraduate institute of general medicine at GSVM medical college Kanpur from December 2017 to March 2019.

\section{Inclusion Criteria}

- Type 2 diabetes mellitus male patients.

- Disease of at least 5 years duration.

- Consenting

\section{Exclusion Criteria}

- Very sick type-2 diabetes mellitus male patients

- Patients with other comorbidities not related to type- 2 diabetes.

Statistical Analysis: The data was collected and entered in MS excels and master chart was made. The data was analysed using appropriate statically tools (SSPE) like percentage means using student $t$ test and level of significance was set at $p$ value

\section{Observation}

Table - 1 Mean Serum Testosterone Level in Type Ii Diabetes

\begin{tabular}{|l|c|}
\hline Mean Testosterone & Type II Diabetes Patients \\
\hline Mean & 98.88 \\
\hline S.D. & 68.07 \\
\hline
\end{tabular}

The value of mean serum testosterone level in type II Diabetes mellitus patients is $98.88 \pm$ $68.07 \mathrm{ng} / \mathrm{dl}$

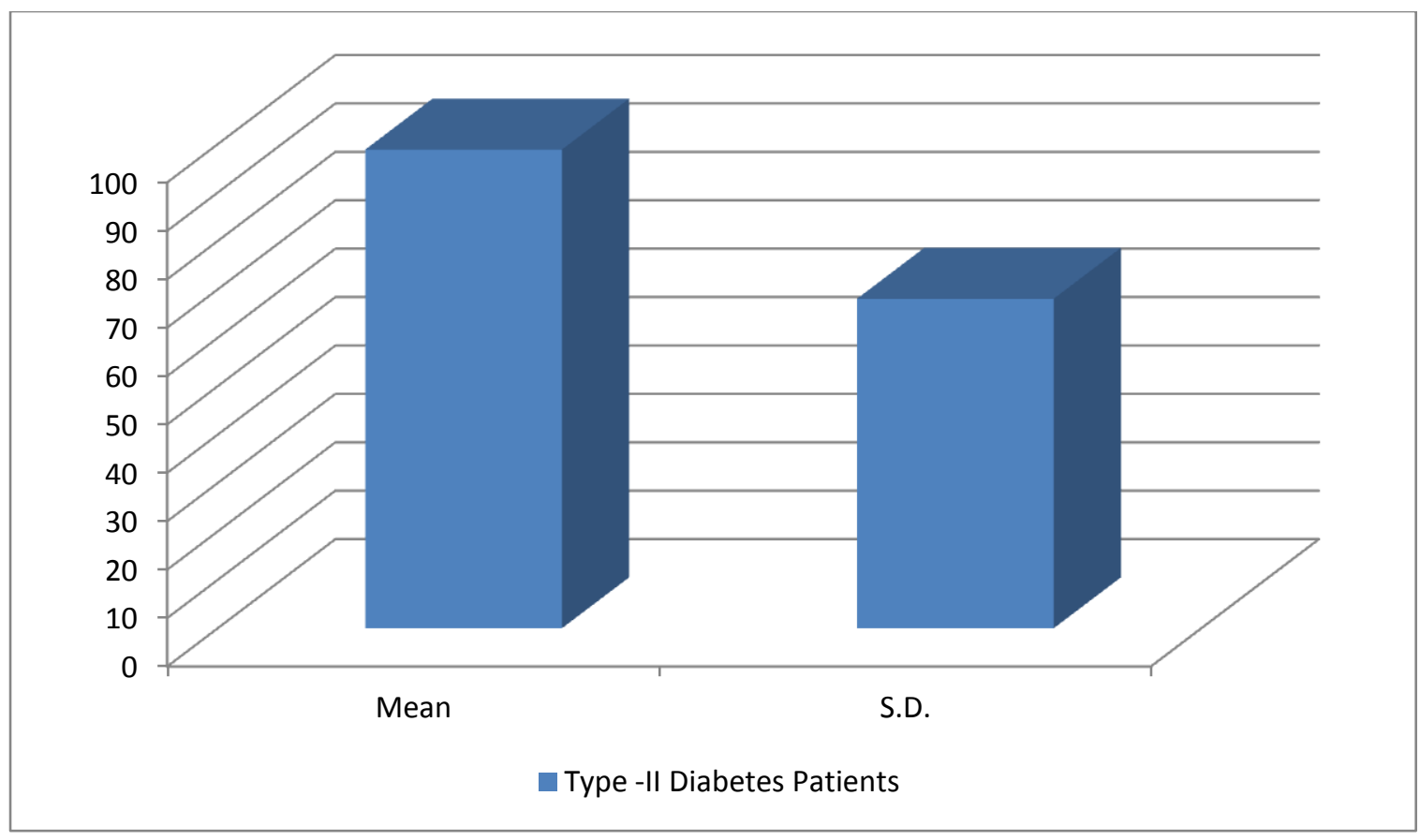

Table - 2 Age Distribution of Study Subjects

\begin{tabular}{|l|c|c|}
\hline Age Yrs & \multicolumn{2}{|c|}{ Group Metabolic syndrome } \\
\hline & No & $\%$ \\
\hline $40-50$ & 6 & 8.9 \\
\hline $51-59$ & 16 & 23.8 \\
\hline $60-70$ & 45 & 67.2 \\
\hline
\end{tabular}

This study consists of total 67 no of study subjects between the age of 40 to 70 years divided in 3 subgroups as 40 to 49 years, 50 to 59 years and 60 to 70 years having comorbidities of metabolic endocrine syndrome. 
Table - 3 HbA1c among Study Groups

\begin{tabular}{|l|c|c|}
\hline HbA $_{1} \mathbf{C}$ & \multicolumn{2}{|c|}{ Group Metabolic endocrine syndrome } \\
\hline & No & \% \\
\hline$>8$ & 48 & 71.6 \\
\hline$<8$ & 19 & 28.4 \\
\hline
\end{tabular}

On the basis of HBA1C patient population was divided into 2 subgroups HBA1c $>8 \%$ and $<8 \%$ metabolic syndrome patient having Hbalc $>8 \%$ were $71.4 \%$ patients and Hba1c $<8 \%$ in $28.4 \%$ patients.

\section{Discussion}

The analysis of 67 patients were done in my study and in which people were suffering from type 2 diabetes mellitus and metabolic syndrome were included. The level of serum testosterone was estimated in all the patients and it was correlated with these diseases. As this type of study was also done in other parts of the world low serum testosterone level have been reported in men with type 2 diabetes mellitus (kitty kit ting cheung et al 2015) and (cheungkk et al 2017) inverse relationships between the serum testosterone level and cardiovascular risk factors, such as obesity, hypertension, dyslipidemia and insulin resistance, have been observed. The patients seen in cross sectional study constituted total 67 no of study subjects between the age of 40 to 70 years divided in 3 subgroups as 40 to 49 years, 50 to 59 years and 60 to 70 years. $8.9 \%$ patients were in 40 to 49 years $23.8 \%$ patients were in 50 to 59 years, $67.2 \%$ patients were 60 to 70 years group

On the basis of Hbalc patient population was divided into 2 subgroups Hbalc $>8 \%$ and $<8 \%$. Metabolic syndrome having hba1c $>8 \%$ in $71.6 \%$ patients and hba1c $<8 \%$ in $28.4 \%$ patients according to the study done bydandona $\mathrm{p}$ et al $(2011)^{17}$ the subnormal testosterone concentrations are not related to glycosylated hemoglobin or duration of diabetes, but are associated with obesity.

According to the study done by corona $\mathrm{g}$ et al (2007) 7 logistic multivariate regression analysis, incorporating the five components of metabolic syndrome identified a significant association of elevated

waist

circumference

and

hypertriglyceridemia with hypogonadism both in patients, with or without $\mathrm{t} 2 \mathrm{dm}$.

\section{Conclusion}

Based on the data of 66 patients of diabetes mellitus seen in GSVM Medical College Kanpur, the conclusions are-

1. The most common age of occurrence of CHD, CKD, MES in patients of type 2 diabetes is 60-70 years.

2. The mean value of serum testosterone in male patients of diabetes mellitus type 2 is $92.79+-68.07 \mathrm{ng} / \mathrm{dl}$.

3. The mean value of serum testosterone level in patients of diabetes mellitus type 2 having metabolic syndrome is 92.79+$68.7 \mathrm{ng} / \mathrm{dl}$.

4. The patients having high values of HBA1C ie $>8$ are more prone to developed METABOLIC SYNDROME.

\section{Bibliography}

1. Akishita M, Hashimoto M, Ohike $\mathrm{Y}$, et al. Low testosterone level as a predictor of cardiovascular events in Japanese men with coronary risk factors. Atherosclerosis. 2010; 210:232-236.

2. Alberti KG, Eckel RH, Grundy SM, Zimmet PZ, Cleeman JI, Donato KA, Fruchart JC, James WP, Loria CM, Smith SC Jr; International Diabetes Federation Task Force on Epidemiology and Prevention; Hational Heart, Lung, and Blood Institute; American Heart Association; World Heart Federation; International Atherosclerosis Society ; International Association for the Study of Obesity : Harmonizing the metabolic syndrome: a joint interim statement of the International Diabetes Federation Task Force on Epidemiology and Prevention; National Heart, Lung, and Blood Institute; American Heart Association; World Heart Federation; 
International Atherosclerosis Society; and International Association for the Study of Obesity. Circulation. 2009 Oct 20;120 (16):1640-5.

3. Araujo AB, Dixon JM, Suarez EA, et al. Clinical review: Endogenous testosterone and mortality in men: a systematic review and meta-analysis. J Clin Endocrinol Metab. 2011;96:3007-3019.

4. Bhasin S, Cunningham GR, Hayes FJ, et al. Testosterone therapy in men with androgen deficiency syndromes: an Endocrine Society clinical practice guideline. J Clin Endocrinol Metab. 2010;95:2536-2559.

5. Cheung KK, Lau $\mathrm{ES}^{2}$, So $\mathrm{WY}^{2}$, Ma $\mathrm{RC}^{3}$, Ozaki $\mathrm{R}^{2}$, Kong $\quad \mathrm{AP}^{3}$, Chow $\mathrm{FC}^{2}$, Chan $\mathrm{JC}^{3}$, LukAO : Low testosterone and clinical outcomes in Chinese men with type 2 diabetes mellitus - Hong Kong Diabetes Registry. Diabetes Res Clin Pract. 2017 Jan;123:97-105.

6. Corona G, Mannucci E, Petrone L, et al. NCEP-ATPIII-defined metabolic syndrome, type 2 diabetes mellitus, and prevalence of hypogonadism in male patients with sexual dysfunction. J Sex Med. 2007;4:1038-1045.

7. Corona G, Monami M, Rastrelli G, et al. Testosterone and metabolic syndrome: a meta-analysis study. J Sex Med. 2011;8:272-283.

8. Corona G, Monami M, Rastrelli G, et al. Testosterone and metabolic syndrome: a meta-analysis study. J Sex Med. 2011;8:272-283.

9. Dandona P, Dhindsa S. Update: Hypogonadotropichypogonadism in type 2 diabetes and obesity. J Clin Endocrinol Metab. 2011;96:2643-2651.

10. Gail A. Laughlin, Vivian Goodell, and Elizabeth Barrett-Connor : Extremes of Endogenous Testosterone Are Associated with Increased Risk of Incident Coronary
Events in Older Women. J Clin Endocrinol Metab. 2010 Feb; 95(2): 740-747.

11. Jankowska EA, Biel B, Majda J, Szklarska A, Lopuszanska M, Medras M, Anker SD, Banasiak W, Poole-Wilson PA, Ponikowski P : Anabolic deficiency in men with chronic heart failure: prevalence and detrimental impact on survival. Circulation. 2006 Oct 24;114(17):1829-37.

12. Kitty Kit Ting Cheung, Andrea On Yan Luk, Wing Yee So, Ronald Ching Wan Ma, Alice Pik Shan Kong, Francis Chun Chung Chow, and Juliana Chung NgorChan : Testosterone level in men with type 2 diabetes mellitus and related metabolic effects: A review of current evidence. J Diabetes Investig. 2015 Mar; 6(2): 112-123.

13. Kupelian V, Hayes FJ, Link CL, et al. Inverse association of testosterone and the metabolic syndrome in men is consistent across race and ethnic groups. J Clin Endocrinol Metab. 2008;93:3403-3410.

14. Laaksonen DE, Niskanen L, Punnonen K, et al. Testosterone and sex hormonebinding globulin predict the metabolic syndrome and diabetes in middle-aged men. Diabetes Care. 2004;27:1036-1041.

15. Liao $\mathrm{CH}$, Huang $\mathrm{CY}$, Li $\mathrm{HY}$, et al. Testosterone and sex hormone-binding globulin have significant association with metabolic syndrome in Taiwanese men. Aging Male. 2012;15:1-6.

16. Ohlsson C, Barrett-Connor E, Bhasin S, et al. High serum testosterone is associated with reduced risk of cardiovascular events in elderly men the mros (osteoporotic fractures in men) study in sweden. J Am CollCardiol. 2011;58:1674-1681.

17. Ozkan Gungor, "Fatih Kircelli, Juan Jesus Carrero, Gulay Asci, Huseyin Toz, Erhan Tatar, Ender Hur, ${ }^{*}$ Mehmet Sukru Sever, TurgayArinsoy, ${ }^{* 1}$ and Ercan Ok: Endogenous Testosterone and Mortality in Male Hemodialysis Patients: Is It the 
Result of Aging? Clin J Am SocNephrol. 2010 Nov; 5(11): 2018-2023.

18. Salminen M, Vahlberg T, Raiha I, et al. Sex hormones and the risk of type 2 diabetes mellitus: A 9-year follow up among elderly men in Finland. Geriatr Gerontol Int. 2014.

19. Shores MM, Matsumoto AM, Sloan KL, Kivlahan DR: Low serum testosterone and mortality in male veterans. Arch Intern Med. 2006 Aug 14-28;166(15):1660-5.

20. Simon D, Preziosi P, Barrett-Connor E, et al. Interrelation between plasma testosterone and plasma insulin in healthy adult men: the Telecom Study. Diabetologia. 1992;35:173-177. 